\title{
Sumptuous clothing and ornamentation in the Apocalypse
}

\author{
Dietmar Neufeld ${ }^{1}$ \\ University of British Columbia, Vancouver Canada \\ Research Associate: Department of New Testament \\ University of South Africa
}

\begin{abstract}
Using different categories of social psychology on body decoration and dress, this article examines the author's course of shifting political, moral, religious and eschatological values as reflected in the clothing and ornamentation motifs deployed in the narrative of the Apocalypse. The article focuses on questions such as the eschatological values betrayed by the author's deployment of clothing and ornamentation themes, the meaning adduced from the passages in the Apocalypse where body surface is taken seriously, ancients' connection of clothing and body decoration with the person and society, and the social values reflected by dress and ornamentation, such as honour/shame, status, boundaries, and identity personally and collectively.
\end{abstract}

Humans are born naked but die and are put away with their clothes on. [Dye] is unnecessary for health, afflicts greedy eyes, and moreover, it is false, for God would have made sheep purple if God had wished the woollen clothes to be purple (Commodianus, $3^{\text {rd }}$ Century $\mathrm{CE}$ ).

Clothes are inevitable. They are nothing less than the furniture of the mind made visible (James Laver, Style in Costume).

\footnotetext{
1 Paper presented at the International Context Group Meeting at the University of Pretoria, June 2001. Prof Dr Dietmar Neufeld visited South Africa as Research Associate of Prof Dr Eugene Botha, Department of New Testament, Faculty of Theology and Religion, Unisa.
} 
The physical body is a social roadmap that is most often condensed and expressed in somewhat compact symbolic form in one's physical person (Bruce Malina, Biblical social values and their meaning)

\section{FASHIONING THE BODY: CLOTHES MAKE THE PERSON}

Agnes Allen (1955:11) writes, "Nature has supplied every animal except human kind with some such covering for his or her body as fur, feathers, hair, scales, shells or a thick hide. But humankind has nothing but a thin skin, and for thousands of years human beings must have wondered about the world with no other covering - though the earliest humans may perhaps have been harrier than modern humans." The accumulation of dress and adornment has both negative and positive connotations. Dress signifies the apparel worn by both men and women but also refers to act of covering the body with clothes and accessories. Hence, we say, "I' am going to get dressed now." Adornment stresses the aesthetic aspects of altering the body in some way. Dress underscores the process of covering or uncovering the body with clothing and accessories (Kaiser 1985:6).

To dress or not to dress and to adorn or not to adorn, that is the question; a matter cast upon first humankind in Genesis. They dressed themselves upon becoming conscious of their nakedness; "and they sewed fig leaves together and made loincloths for themselves" (Gn 3:7). While this first adornment is not conspicuous or sumptuous, cloths inevitably come to be an integral part of the repertoire of human social behaviour and social self-definition. Indeed, clothing and adornment become increasingly sophisticated, as the pragmatics of protection from heat and cold no longer determine primarily the items of apparel worn by humans. What is clear, in clothing and body decoration are found the means of signifying cherished ideals and hated aversions. Clothing functions as a second skin to reveal philosophical, civil, national and religious identity. Dress and ornamentation provides important social, cultural, and religious information concerning power, status, group identity, manufacture, and trade. In others words, people and nations wear their cultural, social, and religious values. In the words of Lurie (1981:30), "The vocabulary of dress includes not only items of clothing, but also hair styles, accessories, jewelry, make-up and body decoration." Clothes and adornment speak 
volumes - a language that speaks literally and metaphorically through the material, colour, shape, size, and texture of material (Lurie 1981:31).

In modern society, as an example, the colour black conveys meaning at several levels - "Black is sophisticated, slimming and flattering to the face, as portrait painters from Rembrandt to Sargent knew; both pale and brown skins warm up and glow above it. But if you're looking a bit unhealthy, black can finish you off; it's very harsh against sallow or greyish undertones. Black also attracts opposites. It is in fact a bundle of opposites. The priest and the biker, the widow and the vamp, the beatnik and the puritan: all are known by their black clothes" (Peacock 2000).

Maybe the real reason for black's universal appeal is that it is such a versatile void, always ready to be filled with whatever meaning one wants to assign - as long as it is a powerful statement. Black is often linked in people's minds with aggression and power (Peacock 2000). Clothing and adornment in their various forms (colour, texture, shape, size, etc) are used to modify body surfaces and these modifications have meaning for people interacting with each other. Clothing and adornment then have shared meaning for people particularly when it comes to fashion. Fashion is defined as a form of "collective behaviour that is socially approved or disproved at any given time. Fashion related to clothing style then refers to what is accepted and worn by many members of society at a given moment" (Kaiser 1985:8). Attire and adornment provide a visual medium through which individuals and communities communicate cues about themselves and their social setting. Moreover, as in other forms of non-verbal communication (gestures, facial expressions, bodily stance), dress and adornment provide symbols and cues that people use to understand not only each other but also the communal ethos and social hierarchies within that community. The style of attire and adornment adopted by collective groups of people reflect communal norms and social values. Clothing norms signify forms of collective behaviour. Group membership, group values, group status, may be communicated through attire and adornment. Maintenance of or departure from communal norms may be symbolized in a variety of actions and behaviours reflected in that of apparel and accessories.

The vocabulary of clothing and adornment includes actions and behaviours anomalous dressers (cross dressers; transvestites), robing or disrobing, stripping or being stripped, partially clad or fully clad; which body zone is covered or uncovered, head, 
eyes, neck, feet, thigh, breast, face, abdomen, buttocks; which part of the body is doubly clothed; what item of apparel is put on first, last, in which order, from the bottom up, top down, or middle moving outwards. Choice of colour, style, fabric (linen, leather, denim, lace), shape, size, et al., are integral to the vocabulary of attire and adornment - each of these elements may be used to construct an appearance (individual or communal) for maximum public effect (Philo, On Joseph 120; Josephus Ant 11.254; 19.344; Ac 12:21; Josephus $J W 2.29$ ).

\section{FUNCTION OF DRESS AND ORNAMENTATION}

Attire and adornment have a vocabulary because of their inherent symbolism. Consider the scope of information possible: one's sex, age, group, nationality, religious affiliation, means of livelihood, social, economic, and marital status, political or military rank, personal achievements, loyalties, beliefs, and values, family connections, and trade or profession (red fingernails, rompers, lederhosen, fireman's helmet, sport's headgear, club tie, sable coat, wedding ring, judge's robes, sergeant's stripes, cap and gown, political buttons, the tartan kilt, veil, sun glasses, and mitre, etc). Anthropologist's index symbolic dress and adornment under four general categories: totemic, trophyism, hieratic, and emblematic (Batterberry 1977:12-14). Totemism refers to the desire of humans to imitate as closely as possible an animal, bird or plant. Imitation by wearing the skin of an animal, took on mystical significance especially in the case of the hunt. Trophyism refers to the desire of advertising excellence or superiority of character and deed. Dressing in wild animal skins, accessorizing with wearable bits of anatomy, human or animal, such as claws, teeth, tusks, skulls, skin/foreskins (1 Sm 18:24-27)), fangs, scars and bloodstains, scarification, tattooing, and body paint were evidence of courage, bravery in battle, fearlessness, and honour. Belts, mace, and sceptre were potent symbols of power and authority. Hieratic refers to the desire to keep society visibly stratified. This is seen in the vast corpus of sumptuary laws that has been inflicted on people since ancient times. Sumptuary laws attempt to limit the amount that certain people or classes may consume or display (Batterberry 1977:14). Hieratic forms of attire are often most visible in the military, judiciary, and clergy. As such, uniforms, occupational dress, status attire and athletic outfits are emblematic often expressing particular convictions, values, attitudes and beliefs. 
"Why people wear what they wear?" is a question posed by psychologists, sociologists, anthropologists, political scientists, art historians, and the costume archivist. Humans choose to transform themselves in astonishing ways, whether for the sake of the flesh or spirit, for themselves or the eyes of the beholder, for reasons of lust, ambition, shame, honour, status, fear, and piety. Taking note of the human propensity to decorate body surfaces, social scientists, anthropologists and psychologists suggest a number of functions of attire and adornment.

\subsection{Pragmatic function}

While items of apparel were initially worn for practical purposes such as protection from the elements, diversity in apparel and decoration nevertheless quickly developed. Gender, tribal affiliation, status, and social order were soon signalled by body decoration and clothing.

\subsection{Impression management function}

In the social contexts of human interaction, clothes and related accessories are part of an individual's identity kit (Goffman 1965:246). These identity kits help humans to play out their social roles and lend credibility to those roles. Clothing and decoration communicate meaning because of the socially determined symbolism inherent in them. As such then, clothing and decoration provide important cues to aid interpersonal and intrapersonal communication. Clothing and decoration have value from the wearer's perspective in conveying a desired impression (sexual, status, rebellion, power, and gender). This process is called impression management: "it involves the control of appearance-related impressions that are communicated to others during social interaction" (Kaiser 1985:19). Impression management is a social process that results from impressions the wearer has of her/himself relative to the community and its standards and values. Either deliberately breaking clothing and decoration conventions or flaunting the conventions by wearing ostentatious clothing signals the wearer's perspective of her/himself relative to her/his community. John the Baptist's garments of skin create an appearance related impression by which he communicates something about his perceived role and identity within a community. The leather garments do not just fall on the Baptist involuntarily. A deliberate choice is involved in which his perceived identification with 
the classical prophets determines the selection of what the Baptist wears - an appearancerelated impression that communicates his role as a prophet. Moreover, the attire also communicates that his role is to play itself out on the margins of society.

The New Testament records that observant Judeans wear decorations called tassels on their garments. These decorations accentuated the hem of the garment so that the more important the person the more flashy the embroidery on the hem of the robe. The ornamentation of the hem of the garment created appearance-related impressions designed to communicate status but also degrees of piety - an intentional control of one's appearance in a public space and the impressions it created. Observers of those wearing ornately embroidered robes used clothing cues to assist them in understanding not only motive, but also degrees of piety and status - generally referred to as impression formation. Josephus records that King Agrippa intentionally amazed the crowd in the theatre when he entered attired in a garment "woven completely of silver so that its texture was indeed wondrous." In the sun, the king's cloak "was wondrously radiant and by its glitter inspired fear and awe on those who gazed intently upon it" (Ant 19.344; Ac 12:21). Agrippa, as wearer of this robe to the theatre, certainly appears to regard appearance-related impression management as important. He deliberately controls, through his choice of dress in public, impressions of how he regards himself, his status as king, and his effect on the crowd - it was filled with fear and awe. Wearing the dazzling robes to the theatre contributed significantly to the audience's impression formation of Agrippa: they recognized him as powerful and not one with whom to be trifled. He was a power wielder who was entitled to privileges and must appear as mighty and powerful as possible (Malina 1993:82).

\subsection{Extension of persona function}

Dress and adornment contributes to the enhancement of one's external bodily self or persona. Here situational, social, and status contexts will determine not only role but also the manner in which dress and adornment function as an extension of the body and self. First, attire and adornment extends the bodily self in terms of an increase in a sense of movement. Agrippa attired in his dazzling robe, Herod in his royal robes, and the observant in their garments of showy hemlines, increased the flow of movement and spectacle in public space. It consequently rendered the sense of importance to each of 
these characters and also exaggerated their actions of religious piety in public - praying, and alms giving, et cetera. Agrippa's silver cape in the theatre contributed to his sense that he was super king with the attendant feelings of honour. The whore of Babylon wears garments of luxury full of colour, excessive material, and multilayered precisely because it was eye-catching in terms of movement and display. In an honour shame society such display amounted to much except, of course, when pilloried by those who objected to ostentatious display. Second, clothing and accessories increase the apparent size of the body and contribute to the wearer's power, authority, and higher status and honour (Kaiser 1985:41). The priestly vestments were designed to cover the body in multiple layers, each layer exaggerating the size of legs, torso and head. Moreover, the textures and colours of the different materials heightened the impression of size and imbued them with power and authority in the context of holiness and separation from the people. These priestly accoutrements also contributed to an extension of the bodily self in terms of genealogy, gender, choice, station, actions, a body unblemished, et cetera. John the Baptist's leather vests him with the authority and power of the prophet - he is not a reed shaken by the wind. Soft robes, fine clothes of royalty and royal palaces all contribute to an extension of the wearer's persona, but stand in opposition to the enhancement of the Baptist's body (Lk 7:24-26).

\subsection{Sexual attraction function}

Dress and adornment plays a function in displaying or emphasizing certain attributes of the physical body as well as concealing them for purposes of sexual attraction. Anthropologists have argued that the body covered or selectively revealed is more erotic than one totally exposed. What is erotic and what should be covered or exposed is subject to social and historical variation. James Laver discusses the idea of shifting erogenous zones where, for example, parts of the body gain what he called erotic capital if covered up long enough to render some intrigue. Those parts of the body with too much exposure over a period of time he called sterilized zones. Body parts in that zone have suffered from long public exposure so as to render them unappealing sexually. For example, in the 70's women's legs became a sterilized zone because of too much exposure through the style of the miniskirt (Laver 1969). Style, fabric, colour, shape, size of attire, what is exposed or not, how exposed, subtle or otherwise, what is accentuated or concealed give 
the body in its totality or in its individual parts erotic capital to render intrigue. As we have pointed out in our inventory of clothing deployment in the bible, jewels and dress gave the human body and the community metaphorically certain erotic capital that created intrigue and was therefore to be avoided. Both sumptuous and scanty dress along with the accessories worn by some in ancient Israelite society and by some in the surrounding nations became fodder metaphorically to pillory the practices, customs, actions, and values of ancient Israelite society and her neighbours.

\subsection{Status expression function}

Clothes are symbolic indicators of status. The display of status through clothing and ornamentation appears to be a universal phenomenon. Attire and adornment is used to display wealth through the consumption of apparel visibly expensive or fashionable, to demonstrate prowess or skill in certain areas, to indicate religious piety or affiliation, to reveal a state of mourning or joy, to exhibit achievement, to indicate a marginalized state, to show a repentant state, to make publicly visible social stratification, to signal honourable and shameful status, and to demonstrate purity and impurity. The colour of an item of apparel also serves as display for status and identity. For example, in the armed forces of the USA, the Green Beret is to be exchanged for a new black beret to unify the force of soldiers who wear them. Many Rangers are outraged because they say that their berets are unique badges earned with blood and courage through centuries, and they do not want them to be handed out to cooks and clerks (Stone 2001:1). In the push to be distinctive, Rangers now tout tan as their universal and unifying colour. "Ranger officials say tan recalls the buckskin of Rogers' Rangers in the French and Indian war, the "butternut" of Mosby's Rangers in the civil war, the colour of the beaches at Normandy in World War II, the "khaki" of Korean and Vietnam-era Ranger uniforms, and the colour of sand in Grenada, Panama, Iraq and Somalia - where Rangers have fought and died" (Stone 2001:1).

\subsection{Honour/shame/purity/impurity function}

A man's physical body appropriately attired and adorned served as a stage on which honour was displayed and claimed. Clothes and ornamentation as part of this public exhibition served to express the value of honour in a variety of ways (gender, class, trade, 
role, religious identity and affiliation, ethnic origins, communal allegiances). Clothing also revealed values related to holiness, wholeness, purity and pollution. Attitudes to purity and pollution determined not only what one wore, where, with whom, in which situation, but also determined the colour, fabric, pattern, and style, of what one wore. White, blue, purple, and scarlet were the colours of the gods, priests, profligates, saints and monarchs, either in combination or singularly. Silks, satins, linens, leather and wool draped the body of priests, kings, commoners, rebels, and the dissolute. Mixed or unmixed fabric, stitched or unstitched, embroidered or unembroidered, and draped or fitted adorned the bodies of monarchs, priests, rebels, and commoners. The number of pieces of raiment, whether one, three, four, eight, and twelve, attired the bodies of peasants, apostles, priests, revolutionaries, prisoners, martyrs and saints. Frequency and ritual in laundering clothes indicated not only status but also a concern for purity: being in contact with disease or other impurities, accidental or otherwise, required ritual purification of outer apparel. Attitudes to purity were also signalled by which zone of the body was exposed, covered, draped, highlighted, ornamented, and accentuated.

\subsection{Apotropaic function}

Items of jewellery and apparel are worn to ward off demons, spirits, and other hostile forces. Items of jewelry such as the amulet, ring, bracelet, and necklace were worn as precautions to avoid the hostility of the gods and goddesses. Frequently, specific prescriptions of apparel for protection are mentioned in the PGM. For example, when seeking divination, often a dangerous activity, being dressed in the garment of prophet, shod with fibres of the doum palm and your head crowned with a spray from an olive tree - the spray should have single-shooted garlic tied around it, affords protection (PGM IV 930-1114). Colour in and of itself functioned to protect the wearer. Scarlet, bluish purple, and fiery purple were considered to perform a powerful apotropaic function against the evil eye (Pilch 1999:19).

\section{THE BODY AND CLOTHING}

The body understood as a social construct, permits individuals and communities to invest the various parts of the body with meaning and significance in alignment with their social systems and values. Included in this investiture of the physical body is decoration and 
covering. The physical body, both attired and ornamented, partially covered, unclad, or zonally clad functions as a social landscape in condensed form to signal symbolically gender, nationality, trade and social position, elite status, poverty, religious orientation and status, and political, philosophical, moral and eschatological ideals. Articles of clothing and accessories are imbued with power to evoke images either of grandeur and splendor or perfidious decay and wanton behavior. Indeed, the ubiquitous deployment of clothing and adornment motifs in a broad range of ancient literature, Greek, Roman, Hellenistic, Jewish, and Christian is testament to the power of the body attired and decorated to display values of various kinds.

Clothing functioned as a second skin to signify cultural, social, religious, eschatological and philosophical values. Moreover, based on what was worn, the wearers were socialized into communities and roles. Ancient persons dressed and adorned themselves to play their part on the social stage and signified in their idiosyncratic costume their obligations, responsibilities and station in life. The color, texture, shape, type of material, the body zone uncovered or covered, arrangement of clothing and ornamentation were charged with positive or negative values to convey a communal ethos that was reflective of a particular world view. In the words of Maier (2002:1),

In dressing in a certain way, or in paying particular attention to costume, one not only played a role but dressed for it and these in turn expressed defining cultural themes and narratives. Thus could a scripted performance lead one on a journey whose unfolding story was strewn with clothes - literally into tyranny, gentlemanly statesmanship, philosophical apatheia, national restoration, purity, conversion, and ascetic freedom from the nudging seductions of the flesh.

Given the desire for honor and the avoidance of shame, external display counted for much. Clothing display and adornment (sumptuous or not) advertised fears and ideals and became part of the interminable game of push and shove - where honor and shame, their loss or gain, were at stake (Horden \& Purcell 2000:488-523). Clothing ideals are part of the larger social world in which social identity is agonistically nurtured and won or lost. 


\section{CLOTHING AS THEOLOGICAL MOTIF}

Sumptuary legislation clearly laid out the rules concerning dress and adornment. Alongside this legislation, clothing and beautifying accoutrements and the actions of robing and disrobing are deployed metaphorically to clarify theological and anthropological values. Both the body and creation are imagined as a perishable garment (Job $10: 11 ; 13: 28 ; 38: 14 ; 39: 19$; Ps 51:6, 8; 65:13; 102:6, 26). God is pictured as adorned in splendid incorruptible garments, light, glory, majesty, dignity, or wearing the weapons of a warrior (Job 40:10; Dn 7:9). The heavenly emissaries are dressed in white, linen, or the clothing of divine holiness and glory (Ezk 9:3, 11; 10:2, 6, 7; Dn 7:9; 10:5; 12:6, 7). Divine punishment and blessing are depicted as garments that one puts on or off (Job $8: 22 ; 29: 14$; Ps 30:11; 34:26; 109:29; 132:9, 16, 18; Pr 31:25). States of being, such as salvation and righteousness, are pictured as garments one puts on (Job 29:14; Ps 131:9, 16). Not surprisingly, the wicked are pictured as robed in vices (Job 8:22; Ps 35:26; Ps $73: 6 ; 109: 18 / 9,29 ; 132: 18)$. God depicted as robed in marvelous incorruptible garments, the unrighteous in corruptible, and creation and the body wearing perishable garments finds its parallel in Ancient Near Eastern texts. In the Descent of Ishtar, deities are similarly portrayed as adorned in robes of grand splendor and glory. The gatekeeper divesting Ishtar of her of bodily ornamentation is a sign of disfavor - the stripping precedes Ishtar's descent into the netherworld. The deployment of clothing motifs and adornment as metaphor and the action of robing or disrobing is used by the writers to depict divine favors, disfavors, power, blessedness, status, honor, and dishonor.

\section{CLOTHING AND NAKEDNESS}

Not unusual is the braggart found nude - a state of opprobrium for one so displayed. In the Hebrew Bible it is used to describe a wide variety of conditions. Israel's relationship to god is often described using the analogy of clothing - as nation clothed with divine characteristics and as a bride dressed to fit the occasion of commitment, choice, and faithfulness. Conversely, Israel is depicted as a whore festooned in jewelry but soon to be stripped as sign of god standing in judgment on her faithless debauchery (Ezk 16:37, 39; 23:10; 29; Lm 1:8; Hs 2, 3, 9; Mi 1:11). Stripping means several things: literally of being stripped of one's garments or of being divested of one's privileges and possessions. 
Take for example Job, he was stripped of his wealth and reduced to a state of abject poverty - from riches to rags (Job 1:1/21; 22:6; Is 20:4). A flaunted nakedness becomes symbol of sexual precociousness and the corruption of the nation Israel (Ezk 16:36/9; 23:18). Nakedness is also associated with human creatureliness and what are the furthest limits from god (Gn 2:25; 3:7; Job 1:21; Qoh 5:15). Because of one's creatureliness and the religious power inherent in nudity, one is required to cover up one's nakedness before God (1 Sm 19:24). Priest's, in particular, were enjoined to cover up their nakedness - not to do so meant that they were shaming God and challenging the power and supremacy of God (Neyrey 1998:24-25, 64-66, 205; Neyrey 1993:119-125; Pilch \& Malina 1993:122). Ecstasy and nakedness are sometimes seen as going hand in hand.

The Yahwist creation account has Adam and Eve dress themselves after they discover their nakedness - an act driven as much by shame as arrogance. In the act of covering up, so to speak, they arrogate to themselves an action that was JHWH's privilege. In the Epic of Gilgamesh, the deity in the drive to domesticate Enkidu dresses him - it is not something he does for himself (Job 10:11; Ps 102:26; 104:6; Zch 3:4/5). In certain of the Levitical texts, prescriptions against nakedness express social customs connected to shameful or unclean sexual activity (Lv 18:6/19; 20:11, 17/21). Deliberate, involuntary stripping, or enforced nudity invoked maximum humiliation and shame (Is 20:4; $2 \mathrm{Sm} \mathrm{10:4;} 1 \mathrm{Chr}$ 19:4). In some instances, the removal of clothing is regarded as a sign of respect in the presence of deity, royalty or other very important persons (Rosencranz 1972: 196). Generally, however, uncovering the body is regarded with opprobrium and censured. Nudity is linked with the issue of honor and shame and purity and pollution. Since, clothing marked body boundaries nudity erased those boundaries and the social clues revealed by clothing - a body displayed blurred social distinctions, distinguishing signs of status, and marks of communal identity (Rosencranz 1972:123125).

Body parts were also endowed with value or as possessing degrees of honour. Generally the head, face and eyes were endowed with considerable nobility and were used strategically in the game of push and shove (Neyrey 1998: 24-25; 64-66). Shame and honour are written on the face; by veiling it one takes refuge in anonymity. The right and left hand and feet were regarded as each possessing differing and declining degrees of value. The penis and testicles because of what they implied, the potency and fecundity 
of the male, were considered noble parts and therefore not for public display (1 Cor 12: 23-24; Josephus $J W 2.224 ; 2.148-149)$. Even disrobing in the privy involved a specific body posture - sitting down not standing up and not facing the east west axis - that did not expose the penis or buttocks before God - it implied an insult. Furthermore, the penis and testicles were regarded as symbols of honour - "male honour is symbolized in the testicles and covers typically male behaviour, running from the ethically neutral to the ethically valued: manliness, courage (the willingness to challenge and affront another male) authority, defence of the family's honour, concern for prestige, and social eminence..." (Malina 1993: 51).

\section{NEW TESTAMENT/CONTEMPORARY CHRISTIAN LITER- ATURE}

\subsection{Introduction}

A predominate feature of the New Testament are the references to clothing and adornment in an apocalyptic and eschatological context. Metaphorical applications, depictions of, and exhortations concerning dress, deportment and adornment of the individual and community reflect an identity of being an elect person broken with the world and living in op position to its values. Clothing reflections bespeak of persons redeemed and no longer subject to fleshly appetites - building on pagan philosophical ascetic themes of restraint. The goals, however, are reintegrated into a soteriological and eschatological frame. References to clothing are used to cultivate an adherence to ethical and communal ideals of being separate from the world.

\subsection{Apocalypses}

New Testament apocalypses as well as extra-canonical apocalypses deploy clothing and adornment motifs frequently to express eschatological, ethical and theological values. These ideas often stand in opposition to the prevailing communal, city, and cultural ethos of the day. In the Apocalypse, much attention is given to the white raiment of the aboutto-return Jesus $(\operatorname{Rv} 1: 13 / 6 ; 19: 8 / 16)$. Moreover, those who share in his reign are white- 
robed $(\operatorname{Rv} 3: 18 ; 4: 4 ; 7: 9,13 ; 19: 8)$. The white linen robes of Jesus allude to the garments worn by the priests in the Hebrew Bible and stand in stark contrast with the lurid display of the whore of Babylon and her fornicating paramours who trade in sumptuous regalia $(\operatorname{Rv} 17: 3 / 5 ; 18,12,16)$. It is a burlesque not far removed from Juvenal's satirical exposé of luxury addicted Roman society or the abominable nakedness of the unrighteous ( $\mathrm{Rv}$ 3:17). Sumptuously dressed and appropriately attired characters symbolical become what is to be avoided or imitated. The faithful righteous ones are glorified by heavenly dress and the corrupt ones are glorified by luxurious dress - but in a context that bespeaks their reprehensible wantonness. They have lived intimately with the world and have lost their pure garments. These portraits are derived from the Hebrew Bible and reflect communal ideals of separation from and opposition to a corrupt world with its attachment to luxury. Sometimes, the agents of revelation, evil forces, as well as the resurrected righteous ones are pictured as crowned, clothed in purple, many-coloured garments, or with imperishable garments of divine glory. Faithless men and women are depicted attired in purple and scarlet and garishly festooned with jewelry. Outward display often reveals inner corruption.

\subsection{Clothing and ornamentation and the Apocalypse}

Given the broad functions that clothing and decoration perform, it is not surprising that the writers of the New Testament and Hebrew Bible employed clothing motifs to declare values of a political, philosophical, civic, moral, ethical, theological and eschatological kind. The Apocalypse is no exception to the rule. Take note for example the frequency with which the author deploys clothing motifs. A cast of characters each attired and ornamented differently occupy centre stage and act out their social roles in the narrative of the apocalypse.

\begin{tabular}{||l||l||l||}
\hline \hline TEXT & CHARACTER & TYPE OF CLOTHING \\
\hline \hline Rv $1: 13$ & "Son of man" & Long robe, golden sash \\
\hline Rv 3:4 & "Persons in Sardis" & No soiled clothes; dressed in white; white robes \\
\hline \hline Re 3:17 & "Unnamed braggarts" & Prosperous but naked; need to be clothed in white robes \\
\hline \hline Rv $4: 4$ & "24 elders" & White robes; golden crowns \\
\hline \hline Rv 6:11 & "Persecuted" & White robes \\
\hline \hline Rv 7:9 & "Great multitude" & Robed in white \\
\hline
\end{tabular}




\begin{tabular}{|l||l|l||}
\hline Rv 7:13 & "Great multitude" & Robed in white \\
\hline \hline Rv 12:1 & "Woman" & Clothed with sun; moon under feet; crown of twelve stars \\
\hline \hline Rv 15:5 & "Seven angels" & Robed in pure bright linen; golden sashes \\
\hline \hline Rv 16:15 & "Anonymous" & Clothed; not naked \\
\hline \hline Rv 17:4 & "Woman" & Purple, scarlet; adorned with jewels, gold, pearls \\
\hline \hline Rv 18:16 & "Great city" & $\begin{array}{l}\text { Clothed in fine linen; purple and scarlet,; adorned with } \\
\text { gold, jewels, pearls }\end{array}$ \\
\hline \hline Rv 19:7 & "Bride" & $\begin{array}{l}\text { Clothed with fine linen, bright and pure; fine linen the } \\
\text { deeds of the righteous }\end{array}$ \\
\hline \hline Rv 19:13 & $\begin{array}{l}\text { "Word of God/armies } \\
\text { of heaven" }\end{array}$ & $\begin{array}{l}\text { Robe dipped in blood; armies of heaven, wearing fine } \\
\text { linen, white and pure }\end{array}$ \\
\hline \hline Rv 21:2-9 & "Holy city/bride" & Festooned with jewelry \\
\hline \hline Rv 22:14 & "Anonymous" & Washed robes \\
\hline
\end{tabular}

Most commentators note the clothing descriptions and basically deal with the theological import of the apparel, but few if any deal with the social significance of clothing and ornamentation in antiquity (Mounce 1977:309; Thompson 1990:68, 80; Murphey 1998:355; Boring 1989:178-181; Harrington 1993:171). The eye-catching descriptions of clothing and ornaments worn by the various characters in the Apocalypse signify the cherished ideals and hated aversions of the author (Meier 2002:2; Boyarin 1993:100; Pippin 1992:193-210). Scrutinizing the vagaries of dress and ornamentation in the Apocalypse helps to chart the author's course of shifting political, moral, religious, and eschatological values. The body surface is an especially compelling indexical sign. Bodily signifiers through clothing and decoration present an ever present semiotic for expressing identity and intention, for upholding the status quo or subverting it. Concrete bodily signs are potentially subversive for both onlooker and author since they are easily manipulated by individuals, groups, and authors with different motivations, intentions, design and access to power (Hendrickson 1996:15).

REVELATION 1:13-16. 1:13 and in the midst of the lampstands I saw one like the Son of Man, clothed with a long robe and with a golden sash across his chest. 1:14 His head and his hair were white as white wool, white as snow; his eyes were like a flame of fire, 1:15 his feet were like burnished bronze, refined as in a furnace, and his voice was like the sound of many waters. 1:16 In his right hand he held seven stars, and from his mouth came a sharp, two-edged sword, and his face was like the sun shining with full force. 
As stated earlier, the narrative of the apocalypse is liberally strewn with clothes. A cast of characters occupies center stage each attired and adorned differently. You are what you wear - as pointed out, clothes and jewelry are a part of each character's identity kit that aids in playing out assigned social roles. In $\mathrm{Rv} 1: 13$, the son of man is pictured adorned in a flowing robe with a golden sash encircling his chest. Setting aside for the moment the identity of the son of man (perhaps a celestial formation fleshed out in human form) or whether the clothing signifies priestly status, the attire provides clues about the wearer and the author's values (Malina \& Pilch 2000:38; Aune 1997:93). Clearly the attire is visibly expensive and signals a significant vision of a celestial phenomenon appearing in human form. While not informed of the color of the robe, perhaps it is possible assume that because the sash is golden so also is the robe. It is not unusual for epiphanic Greek poetry to describe beings of celestial significance as attired in brilliant golden robes with accompanying accoutrement. Zeus is described as girding himself with gold about the body, seizing his gold whip and taking his seat in his chariot (Iliad 8:41-46). Poseidon clothes himself in raiment of gold, grasps his gold whip, and takes his stand upon his chariot (Iliad 13:20-27). Callimachus' Hymn to Apollo is typical, "Golden is the tunic of Apollo and golden his mantle, his lyre and his Lyctian bow and his quiver; golden too are his sandals, for rich in gold is Apollo" (32-35). The PGM describe a god immensely big who is golden haired, having a bright appearance, wearing a white tunic and a golden crown and trousers (PGM IV 475-829; 695-699). Heroes are described in epiphanic language wearing similar attire: Aeneas is displayed as splendid in bright light, grand as a god, whose eyes shine out with power...like some work of silver or Parian marble chased with gold (Vergil, 19-20). Warriors often used the sash across the chest or the belt around the waist to secure a dagger or sword (Vergil, Aenead 12.94044).

Judging this celestial phenomenon by its attire and adornment, it is to found in the company of gods, heroes and warriors. The flowing robe, the sash across the chest, the white hair, the eyes of flaming fire, the bronze feet, the thunderous voice, the brilliant face, and the sword in the mouth, are emblematic of grand movement and immense power sweeping the celestial spaces - one thinks of the brilliant, silver and gold, lofty movement of stars across the milky way. This heavenly constellation in human form so attired and adorned is a celestial spectacle sweeping across the sky to warn humans of 
portentous things to follow. The splendiferous, elegant robe and the sash round about the chest render the wearer with immense power, authority, and honor. Words of warning are not enough - humans hear but do not hear so the appeal to the visual. Brilliant color and gleaming gold occupy visual space - it arrests to capture the eyes and open the ears. The robe and golden sash slashing across the chest help to exaggerate the portentous words about to be spoken that concern human beings in the world below. Humans below, take notice of the events that are now happening and the events that will happen soon $(\mathrm{Rv}$ 1:19). To ignore this warning is to do so at your own peril.

In an ecstatic state as a sky traveler, the author of the apocalypse perhaps envisions himself vicariously as a constellation entity wearing the robe and golden sash to create an impression of himself relative to his community and the world in which he finds himself. The celestial garments upon the author create an appearance related impression by which he communicates his status as messenger with a message of immense significance. Moreover, both his status and visionary message are a benefaction from God through Jesus, who has robed him, to warn his community to demarcate its distinction from the nations and its state of holiness and election. Human observers of this heavenly display will hopefully understand not only the desire of the author that his community not be seduced by the cosmos but also, because he is a medium of God through Jesus, that he is entitled to the privileges and power that come with being a sky adventurer. He has been honored to see God's secrets through Jesus about what is soon to happen. So important is the message, that the messenger is wrapped in luxury garments - an ostentatious display designed to render the wearer with a sense of importance, power and honor. He has been faithful to his benefactor Jesus and has been glorified by luxurious dress - with the purpose of conveying opportune words to humans below.

REVELATION 3:4-5. 3:4 Yet you have still a few persons in Sardis who have not soiled their clothes; they will walk with me, dressed in white, for they are worthy. 3:5 If you conquer, you will be clothed like them in white robes, and I will not blot your name out of the book of life; I will confess your name before my Father and before his angels. 
In the ancient world, Sardis was a renowned centre for its opulence, based largely on the extensive mineral deposits in the area. The most famous of these was the gold that was washed down from the Pactolus stream to the city. It was also famous for its fertile plains, described by Strabo (13.4.5-6) as the "best of all plains." The chief products of the plain were grain, wheat, barley, and grapes; the Tmolus wine was famous in the Roman Empire. Vegetables of all kinds, olives, apples, nuts, et cetera, were also produced. With these resources Sardis became a centre of trade and industry in the ancient world. It was famous for its textile industry, the Sardinian purple rugs and goldwoven textiles, couch covers, cushions covered with tapestry, blankets, embroidery, and chitons are all specifically mentioned (Athenaeus, Deipnosophistae 2.48b; Athenaeus, Deipnosophistae 15.690b-d; Vitruvius 2.3.3). According to legend, Arachne produced such a wonderful weaving that she provoked the jealousy of the goddess Athena, who turned her into a spider. Arachne is credited for inventing linens and nets, and her son Closter with the introduction of spindles in wool manufacture (Pliny, Naturalis Historia 7.196).

The reference to soiled garments is sometimes taken to allude to the white garments of those just baptized (Murphey 1998:147). Charles argues that the white garments are an allusion to resurrection bodies (Charles 1920:82-83). Others suggest that cloths here function as a metaphor for a person's spiritual and moral condition (Aune 1997:222). Given the notable textile industry of Sardis, however, and the potential for citizens to wear ostentatious apparel and ornamentation, it is not surprising that the author of the Apocalypse mentions the condition and color of garments to make an important point. As has been shown, bodily surfaces clothed and adorned in certain ways serve as a stage upon which are displayed honor and the values of purity, holiness and communal affiliation. The author informs his readers and hearers that there are some in Sardis who have not permitted their garments to become stained or sullied and who are attired in white. White garments were worn by priests (Ant 11.327, 331; 20.216-18; Ex 28:4; Lv 16:4), worshippers (Ac Jn 38), Essenes (Hippolytus Ref 9.19), heavenly messengers (Hermas Vis 4.2.1; T Lv 8:2; Jn 20:12; Ac 1:10; Mk 16:5; 2 Macc 11:8), and God and Roman deities (Dn 7:9; 1En 14:20). The dead were buried in white, and Jesus is garbed in a white robe at his transfiguration (Mk 9:2; Mt 17:2; Lk 9:29). Malina and Pilch argue 
that the white robes are essentially sky garments draped upon those who have been extraordinarily virtuous, loyal, and righteous. Being draped with the white garment is a benefaction from God to honor those who have not fallen for the seductions of opulence and the defilement potentially possible in Sardis.

Indeed, we are told that their garments are unstained - they have been careful not to get them stained or perhaps when stained, have frequently laundered them to remove the spots. Frequency and ritual in laundering clothes indicates not only status but also concern for purity. They are pure and whole because they have not succumbed to the defilement and debauchery of Sardis. The whiteness of the raiment indicates the purity of the believer. Separation from the idolatrous culture of Sardis is the way to maintain purity. Thus, they are to exchange the dyed apparel of lavish display for the whiteness of unstained display to signal their intention to remain pure and separate from the dominant culture around them. Furthermore, they have resisted capitulating to the world at large and remained faithful to the community of believers in Sardis. Because they have maintained a pure state, they remain blameless before God, the community and the author, they walk in appropriate ways, they are counted as worthy, and they are regarded as conquerors. So dressed, they symbolically become what is to be avoided or imitated.

REVELATION 3:17-18. 3:17 For you say, 'I am rich, I have prospered, and I need nothing.' You do not realize that you are wretched, pitiable, poor, blind, and naked. 3:18 Therefore I counsel you to buy from me gold refined by fire so that you may be rich; and white robes to clothe you and to keep the shame of your nakedness from being seen; and salve to anoint your eyes so that you may see.

Laodicea was a commercial hub renowned for its banking, its textile and carpet industry, and its "Phrygian powder" used in the making of eye salve. Here, once again, the opulence of the city puts its citizens under enormous pressures to capitulate to a life style of wantonness and shameless disregard. While claiming to be prosperous and in need of nothing they are in fact shamefully naked. The reference to nakedness is sometimes taken to refer to bodiless souls but here it would seem to function emblematically best explained in a social context. The close association with the world has corrupted them 
and exposed them for what they really are. Thus, while fully clothed in society's finest apparel, they are nevertheless naked for all to see. As pointed out, in the ancient world the naked body was generally regarded with opprobrium and censure. While living intimately with the world, they have become prosperous in the eyes of the Laodiceans but poor and naked in the eyes of God and the author. They have been stripped of their pure garments and divested of their privileges and possessions before God and the community. Nakedness exposes their creatureliness and what are the furthest limits from god. Their nakedness also symbolically reveals the extent of their corruption, humiliation, shame, and pollution. Under the censure of nakedness, they are clearly marked as those outside the ambit of the community of believers at Laodicea. Indeed, they are wretched, pitiable, poor, and the shame of their nakedness is publicly visible. Since nakedness erases the boundaries marked by clothes, the author enjoins his readers and hearers to purchase white robes with which to cloth themselves. Although it is possible for the white robed ones to refer to the appropriately attired resurrected righteous, here it probably is to be taken as a social metaphor for those who have exchanged ostentatious dress for white robes. The author use clothing references and nakedness to cultivate an adherence to ethical and communal ideals of being separate from the seductive influences of the world. Metaphorical applications, depictions of, and exhortations to being robed in white reflect an identity of being an elect person broken with the world and living in opposition to its values. Being robed in white bespeaks of one who is redeemed and no longer subject to the fleshly appetites of Laodicea.

REVELATION 4:4: Around the throne are twenty-four thrones, and seated on the thrones are twenty-four elders, dressed in white robes, with golden crowns on their heads.

In a trance, the seer has a vision of a heavenly throne room in which is seated one who looks like jasper and carnelian. Around the throne are 24 thrones, and on those thrones are seated 24 elders dressed in white robes, with golden crowns on their heads. These elders, as part of the throne room scene, are appropriately attired in white robes and garlanded about the head with gold. The gold wreath is emblematic of office, distinction, 
honour and glory perhaps of astral beings known as decans (Malina \& Pilch 2000:73). These astral deities, so clad in white and gold wreathed symbolize purity and righteousness and exalted status. As we have pointed out, bodily accessories increased the apparent size of the body, in this case the head, to render a sense of power, authority, and distinction. Moreover, as celestial personages, being robed in white, contributes significantly to the readers and hearers impression formation of the throne room scene. They are power wielders who are entitled to privileges not normally accorded human beings. The scene inspires awe, wonder, and fear. Yet, even though the scene is not part of human experience, those who are robed in white may, however, share in the reign in the reign of God and give their homage to him.

REVELATION 17:4: The woman was clothed in purple and scarlet, and adorned with gold and jewels and pearls, holding in her hand a golden cup full of abominations and the impurities of her fornication;

One of the seven angels approaches the seer, speaks to him and then carries him into the desert in a prophetic trance. While in this state, the seer witnesses a women sitting on a scarlet beast attired and adorned in sumptuous costume - she is dress in purple and scarlet and adorned with gold ornaments, precious stones, and pearls. The woman has been identified with Rome, Jerusalem, or the godlessness of the religions of the world. Each of these suggestions has its detractors and supporters (Aune 1998:936). Assuming for a moment that the seer in this sky journey is viewing portentous celestial phenomena, then, as Malina has argued, the woman represents Venus in the evening sky. The celestial patron of ancient Babylon/Babel was Venus - this sumptuously clad woman then represents the city of Babylon, the archetypical city with its seductions, and its fornicating paramours who traffic in garish garments (Malina \& Pilch 2000:202). In a prophetic trance, the seer envisions Venus in the evening sky in human form, appropriately costumed to play her part in this unfolding celestial spectacle. The portent does not bode well for humankind. Image and sound through voice are combined to convey a message of grave concern to humans below. Brilliantly coloured clothing and extravagant jewelry are an important component of the language of vision in the 
Apocalypse. Without it, the message loses force. A heavenly vision of the cosmos must translate into the sensual world in order for it to be sensible to humans below.

As we have pointed out, the clothing description is probably partially drawn from a courtesan topos - moralist writers, to expose and ridicule vices such as incontinence, profligacy, covetousness, and flattery, used the gaudy wardrobe of courtesans as example of vices to be avoided. Although, a display of sumptuous finery, visibly luxurious, generally signals elite status (royalty, aristocracy, wealth), such display also signals the standing of those given over to dissipation. Porphyry associates purple with carnality ( $D e$ antro 14). Sumptuous finery and decoration creates an impression of dissolute indulgence in sensual pleasure, carnality, and conspicuous consumption. The prostitute's gaudy garment and jewel-encrusted body create an appearance related impression by which she communicates something about her perceived role in the world. Though, she glorifies herself in luxurious dress and accoutrements, the displays symbolically speak of her reprehensible wantonness. It is an ostentatious show for the eyes intended to enflame passionate indulgence in a corrupt world addicted to luxury. The purple, scarlet coloured cloth and the opulent jewels transform the wearer to become what she wears - corrupt, and extend the wearer's body into public space in terms of movement and magnitude - a sweeping grandeur designed to entrap the unwary. The multi-coloured, excessive material and body decoration rendered an exaggerated sense of her reputation, power, authority and honour - do not be fooled, her reputation is to be scorned because it is false. Her attire and adornment, while heavenly, glorifies corruption and reprehensible extravagance.

The brilliant colour of her apparel and the many jewels covering her body emphasize attributes of her physical body for purposes of sexual attraction and seduction. Concealing the body with tantalizing colours and ornamentation creates intrigue and gives her body considerable erotic capital. The intrigue will seductively suck many faithless and unwary ones into her ways and they will become her fornicating paramours. She, though sumptuously dressed, is corrupt and a corrupting influence to be avoided. Why is she to be avoided? Her royal cup is full of scandalous content - idolatry. Blind excessive devotion to this beguiling seductress detracts from worshipping the cosmic 
Christ. The label of the great harlot, though worn by celestial beings with glory and honour, is to be despised and scorned - her judgement is coming.

As patron of Babylon, she embodies metaphorically the place of heavenly power (Malina \& Pilch 2000:207). Malina has shown that the cities mentioned in Revelation are typical of the Mesopotamian rather than Hellenistic tradition (Malina 2000). Because the founder of this type of city is a deity all functions, structures, trade, taxes, and liturgies are subordinate to the deity. As co-residents with the deity, citizens of the city are expected to render honour and obeisance to the deity. It is clear form the Hebrew bible that royalty carried the obligation of promoting allegiance to god and obedience to the precepts of torah. The good fortune of the individual, city and nation rested in the hands of the king. If the monarch dishonoured god through corrupt behaviour, so were the nation and city dishonoured. The seer graphically makes known, through lurid dress and ornamentation, that she has abandoned her responsibility to the inhabitants of the city. Symbolically, the city, rather than encouraging life with god, promotes faithlessness, idolatry and life with Satan.

\section{CONCLUSIONS}

Clothing and ornamentation serve an important function in the Apocalypse. They make vivid through items of covering and decoration not only the identity but also the loyalty of those who are followers of either Satan or the lamb. Apparel and decoration also clearly delineate boundaries, on issues such as who is in/out, pure/impure, and honourable/dishonourable. The author desires to make absolutely explicit the values he both holds dear and despises. There is no room for compromise on these matters. What better way to display the absolute values of the time of the eschatos than through clothing and body decoration. Characters arrayed in certain items of apparel exhibit values that speak louder than words. It appeals to the visual and the sensual - the eye - and reinforces the uncompromising character of the message to the listener/voyeur.

\section{Works consulted}

Allen, A 1955. The story of clothes. London: Faber and Faber.

Aune, D E 1997. Revelation 1-5. Dallas, Texas: Word Book Publishers. (Word Biblical Commentary.) 
Aune, D E 1998. Revelation 6-16. Nashville: Thomas Nelson Publishers. (Word Biblical Commentary.)

Aune, D E 1998. Revelation 17-22. Nashville: Thomas Nelson Publishers. (Word Biblical Commentary.)

Barber, E W 1995. Women's work: The first 20,000 years: Women, cloth, and society in early times. W W Norton, Inc.

Batterberry, M \& Batterberry, A 1977. Mirror, mirror: A social history of fashion. New York: Holt, Rinehart and Winston.

Baumgarten, J M 1991-1992. On the nature of the seductress in 4Q184. Revue de Qumran 19, 133-143.

Bertman, S 1961. Tasselled garments in the ancient Mediterranean. Biblical Archaeology 24, 119-128.

Bonfante, L 1989. Nudity as a costume in classical art. American Journal of Archaeology 93, 543-570.

Boring, E 1989. Revelation. Louisville, Kentucky: John Knox Press.

Boyarin, D 1993. Carnal Israel: Reading sex in Talmudic literature. Berkeley: University of California Press.

Breward, C 1995. The culture of fashion: A new history of fashionable dress. New York: Manchester University Press.

DeBrohun, J B 2001. Power Dressing in Ancient Greece and Rome. History Today 51, $18-25$.

Charles, R H 1920. A critical and exegetical commentary on the revelation of St. John. 2 vols. Edinburgh: T\& T Clark.

Cordell, J M \& Schwarz R 1979. The fabrics of culture: The anthropology of clothing and adornment. New York: Mouton Publishers.

DeSilva, D A 2000. Honour, patronage, kinship and purity. Downers Grove, Illinois: Intervarsity Press.

Culham, P 1986. Again, what meaning lies in colour? ZpapEp 64, 235-245.

Goffman, E 1965. Identity kits, in Roach, M A \& Eicher, J B (eds), Dress, adornment, and the social order. New York: John Wiley \& Sons, Inc.

Goffman, E 1959. The presentation of self in everyday life. Garden City: Doubleday. 
Gullberg, E \& Äström P 1970. The thread if Ariadne: A study of ancient Greek dress. Göteborg: Paul Äströms Förlag.

Harrington, D J 1993. Revelation. Collegeville, MN: The Liturgical Press. (Sacra Pagina.)

Harris, C \& Johnston, M 1974. Figleafing through history: The dynamics of dress. New York: Atheneum.

Hendrickson, H (ed) 1996. Clothing and difference: Embodied identities in colonial and post-colonial Africa. London: Duke University Press.

Hollander, A 1978. Seeing through clothes. New York.

Horden, P \& Purcell, N 2000. The corrupting sea: A study of Mediterranean history. London: Blackwell.

Horn, M J 1968. The second skin: An interdisciplinary study of clothing. Boston: Houghton Mifflin Company.

Johnson, K P \& Lennon S J 1999. Appearance and power. Oxford: Berg.

Johnson, M (ed) 1964. Ancient Greek dress. Chicago: Argonaut, Inc.

Kaiser, S B 1985. The social psychology of clothing and personal adornment. New York: Macmillan Publishing Company.

Laver, J 1969. A concise history of costume and fashion. New York: Charles Scribner's Sons.

Lurie, A 1981. The language of clothes. New York: Random House.

McDowell, C 1992. Dressed to kill: Sex, power and clothes. London: Hutchinson.

Malina, B J 2000. The new Jerusalem in the revelation of John: The city as symbol of life with God. Collegeville, MN: The Liturgical Press.

Malina, B J 1993. The New Testament world: Insights from cultural anthropology. Louisville, KT: Westminster.

Malina, B J \& Pilch J J 2000. Social-science commentary on the book of Revelation. Minneapolis: Fortress.

Meier, H 2002. Kleidung, II. Das Reallexikon fuer antike Christentum 19.

Mounce, R H 1977. The book of Revelation. Rand Rapids, MI: Eerdmans. (NICNT.)

Murphey, J F 1998. Fallen is Babylon: The Revelation to John. Harrisburg, PA: Trinity Press International. 
Neyrey, J H 1998. Honor and shame in the Gospel of Matthew. Louisville, KT: Westminster.

Neyrey, J H 1993. Nudity, in Malina B J \& Pilch J J (eds), Biblical social values and their meaning. Peabody, MA: Hendrickson.

Peacock, M 2000. Is the reign of basic black about to be a relic? Http://women.msn.com/women/style.asp

Platt, E E. s v Jewelry, ancient Israel. Anchor Bible Dictionary III, 823-834.

Pilch, J J 1994. A window into the biblical world: Cosmetics and jewelry. The Bible Today 32(5), 300-305.

Pilch, J J 1999. s v Clothes. The liturgical dictionary of the Bible. Collegeville, MN: The Liturgical Press.

Pilch, J J \& Malina B J 1993. Biblical social values and their social meaning: A handbook. Peabody, MA: Hendrickson.

Pippin, T 1992. Eros and the end: Reading for gender in the Apocalypse of John. Semeia $59,193-210$.

Polhemus, T 1978. Fashion and anti-fashion: An anthropology of clothing and adornment. London: Thames and Hudson.

Prouser, O H 1998. Clothes maketh the man. Bible Reviev 14, 22-27.

Prouser, O H 1996. Suited to the throne: The symbolic use of clothing in the David and Saul narratives. Journal for the Study of the Old Testament 71, 27-37.

Roach, M E \& Eicher, J B (eds) 1965. Dress, adornment and the social order. New York: John Wiley \& Sons, Inc.

Rosencranz, M L 1972. Clothing concepts: A social-psychological approach. New York: The Macmillan Company.

Rudofsky, B 1971. The unfashionable human body. Garden City, NY: Doubleday \& Company, Inc.

Stone, A 2001. Rangers press for tan berets. USA Today.

Thompson, L 1990. The book of Revelation. New York: Oxford University Press.

Wilkins, J 2001. The boastful chef: The discourse of food in ancient Greek comedy. Oxford: Oxford University Press. 